\title{
The Influence of Height on Academic Outcomes*
}

\author{
Devon Gorry
}

Utah State University

devongorry@gmail.com

August, 2016

\begin{abstract}
This paper examines whether the height premium for academic outcomes is driven by unequal opportunities for tall individuals. Using data from the National Longitudinal Survey of Adolescent Health, this paper shows that taller individuals typically earn higher grades and attain more schooling, but the associations are not uniform across school size. Height is only associated with better outcomes for students attending large schools and these improvements are concentrated among males. Data suggest that height contributes more to sports participation and school satisfaction in large schools where resources are more scarce. Thus, differential opportunities or treatment across height in large schools may drive the performance differences.
\end{abstract}

${ }^{*}$ I thank Steve Levitt, Emily Oster, Andy Zuppann, seminar participants, and anonymous referees for helpful comments. All mistakes are my own.

This research uses data from Add Health, a program project directed by Kathleen Mullan Harris and designed by J. Richard Udry, Peter S. Bearman, and Kathleen Mullan Harris at the University of North Carolina at Chapel Hill, and funded by grant P01-HD31921 from the Eunice Kennedy Shriver National Institute of Child Health and Human Development, with cooperative funding from 23 other federal agencies and foundations. Special acknowledgment is due Ronald R. Rindfuss and Barbara Entwisle for assistance in the original design. Information on how to obtain the Add Health data files is available on the Add Health website (http://www.cpc.unc.edu/addhealth). No direct support was received from grant P01-HD31921 for this analysis. 


\section{Introduction}

It has been well established that height is correlated with improved outcomes along a number of dimensions, including educational achievement, labor market outcomes, and health 1 Although taller people have better average outcomes, the reasoning is still debated. Are taller people given more opportunities in school, favored in the labor market, and treated differently than their shorter peers or is height just associated with better childhood environments and a superior cognitive endowment? The answers to these questions have different policy implications. If height leads to differential opportunities for children in school, then policy may improve the disparities.

Persico et al. (2004) find that teenage height, not adult height, matters for labor market outcomes. Their finding suggests that labor market discrimination is not a major factor contributing to the height premium and indicate that adolescent experiences may play a role in the association between height and wages. They argue that taller students could have more access to clubs or social activities that develop human capital and lead to improved labor market outcomes. Thus, even without discrimination in the labor market, there may be unfair advantages to being tall during one's school years.

Alternatively, Case and Paxson (2008) provide evidence for a different explanation:

\footnotetext{
${ }^{1}$ Past literature shows that taller students perform better in the classroom and on cognitive tasks and attain more schooling (Downie et al., 1997; Case and Paxson, 2008; Cohen, 2009; Heineck, 2009; Case and Paxson, 2010). Papers since early 1900s report that height is associated with improved labor market outcomes such as employment and wages (Gowin, 1915; Loh, 1993; Sargent and Blanchflower, 1994; Behrman and Rsenzweig, 2001; Case and Paxson, 2008; Case et al., 2009; Hübler, 2009; Case and Paxson, 2010). This height premium is often large in magnitude, with taller workers earning 4 to 6 percent more than their shorter counterparts (Loh, 1993). Finally, research indicates that taller individuals also have better health outcomes and live longer (Case and Paxson, 2008b; Cohen, 2009; and Case and Paxson 2010).
} 
average height reflects cognitive ability. Differences in genetics, health, and early environmental factors are related to physical growth as well as cognitive development. Thus, children who are endowed with good genes or grow up in a healthy environment are not only more likely to grow taller, but they also perform better in school and excel in the workplace due to higher cognitive function. This superior cognitive development can cause associations between height and improved outcomes. Case and Paxson (2008) find that height premiums in wages diminish when childhood test scores are included as a proxy for cognitive development. Furthermore, the authors show that taller, healthier individuals achieve their growth spurts earlier in life leading to larger height differences during adolescence. This greater height disparity during teenage years can explain why teenage height is more significant than adult height in the results of Persico et al. (2004).

Given that the literature provides different explanations for the association of height and outcomes, this paper further assesses this relationship by examining whether the associations between height and outcomes are uniform across school size. If taller students are better at capturing limited opportunities or resources as suggested by Persico et al. (2004), then we would expect height to matter more in large schools where there is more competition for scarce resources. Using data from The National Longitudinal Study of Adolescent Health (AddHealth), Table 1 shows that opportunities are more limited in larger schools. Relative to the smallest quartile of schools, the largest quartile of schools has higher student teacher ratios, fewer students participating in school sports, and fewer students in other clubs. In addition, Table 1 shows that fewer students in large schools report that their best friends come from the same school, suggesting that it may be harder to make close relationships in big schools. If height helps one access more school resources or make better connections with teachers and friends, then height should matter more in large schools. If 
these factors affect outcomes, then the association between height and educational outcomes should be stronger in large schools. This paper tests whether height associations differ across school size.

First, this paper confirms that height is associated with improved academic performance. Taller students earn higher grades and attain more schooling, with performance gains driven by improvements for tall males. Next, this paper shows that the relationship between height and outcomes is in fact strongest in large schools. That is, tall male students typically outperform their peers in large schools, but for students who attend small schools height is not correlated with better outcomes. While previous research establishes a link between height and improved outcomes, this paper is the first to show that the association varies across school size. Controlling for health and parental background often diminishes the average height relationship, but it does not eliminate the differential relationship across school size. The results suggest that large school settings may favor tall individuals and contribute to the height premium.

The paper proceeds as follows: Section 2 provides an overview of the data; Section 3 details the differential associations of height across school size; Sections 4 and 5 explore the role of extracurricular participation and school satisfaction in explaining these associations, respectively; and Section 6 concludes.

\section{Data}

AddHealth is a survey of health related behaviors and outcomes of adolescents from middle and high school years into young adulthood. AddHealth is a school-based 
survey that interviewed students from a stratified random sample of high schools and middle schools across the country. Schools were chosen in an attempt to obtain a representative sample of the United States with respect to region of country, urbanicity, school size, school type, and ethnicity. Students within each school were surveyed at random. Due to oversampling in some categories, sample weights are used throughout the analysis. The analysis for this study focuses on a subsample of students who attended non-urban high schools $2^{2}$ This sample includes approximately 67 schools and over 4,000 students. The schools from which students are sampled range in size from 47 students to 2,590 .

AddHealth consists of four rounds of surveys. The first wave of the study, in 1994-95, targeted $7^{\text {th }}$ through $12^{\text {th }}$ graders. In addition to the in-home and parental surveys conducted on the longitudinal participants, an in-school survey was administered to all students as well as a separate survey for administrators. The following year, wave 2 of the study conducted another round of in-home interviews and phone conversations with school administrators. The wave 3 and 4 follow-up surveys occurred from 2001 to 2002 and from 2008 to 2009, respectively. In addition to more in-home interviews, the third wave also gained permission from participants to collect past high school records.

The independent variables of interest are height and height interacted with cohort size. This paper uses physical height measurements that are taken by the interviewer in the second round of surveys.$^{3}$ This height represents a student's height in high

\footnotetext{
${ }^{2}$ Only non-urban schools are used in an attempt to keep other differences to a minimum. Urban schools differ substantially from suburban and rural schools not only due to their very large size, but also on other schooling characteristics such as student resources, population in poverty, and student body composition. Approximately $26 \%$ of the AddHealth sample, which is representative of the U.S., is urban. This is consistent with reports from the National Center for Education Statistics (see U.S. Department of Education, 2005 where they report $28.8 \%$ of public school students in a central city location). The results found in this paper do not apply for urban schools.

${ }^{3}$ Self reported height is also recorded; however, given that self reported height tends to be over
} 
school, which is the relevant height measure if height matters for schooling outcomes. This is also the height that Persico et al. (2004) found to be most predictive of adult wages. Students who were in grade 12 were not contacted for the second round of surveys. Therefore only participating students who initially started in grades 9-11 are included in the study. Cohort size is constructed using the schools reported enrollment, dividing by the total number of grades at the school, and multiplying by the number of high school grades. Thus, the size variable represents the size of the high school cohort at one's school. This is the relevant size variable since this is likely the pool of students that compete for similar resources.4

The dependent variables include outcome data from the first, third, and fourth survey waves. The wave 1 in-school questionnaire asked students to self-report their most recent grades for English, History, Math, and Science. This reported GPA1 variable is an average of reported grades across subjects where $\mathrm{A}$ is coded as $4, \mathrm{~B}$ is coded as 3, $\mathrm{C}$ is coded as 2, and "D or below" is coded as $15^{5}$ While this variable has a large number of responses, it does not include all classes and is subject to measurement error. A GPA2 variable comes from student transcript data obtained in round 3 of the survey, which represents one's combined high school GPA for all classes. However, the sample size is much smaller for this outcome because not all individuals provide transcript access and the measure reflects a different composition of classes across students. The high school diploma variable is generated from wave 3 and 4 responses.

estimated (see Brener et al., 2003) this paper uses the height that is measured by the interviewer. Results, however, are similar with self reported height. Self reported heights as well as third round measured heights are used to find errors in the recording of measured heights. In particular, when self reported height and future measured height are both much shorter or both much taller than the recorded height, it is assumed that the feet were recorded improperly and a correction is made. This only occurs in 6 cases and results are not sensitive to correcting, omitting, or keeping the original measurements.

${ }^{4}$ The results are robust to defining size in other ways such as using school size or class size for schools that have grades 9-12 and defining school size as the size of the 9th or 10th grade cohort.

${ }^{5}$ The question does not differentiate between $\mathrm{D}$ and $\mathrm{F}$. 
In wave 3 respondents are asked to report their high school graduation status. Those responding as having a diploma are coded as 1 while those who respond that they have a GED, a certificate of completion, or none of the above are coded as 0 . If wave 3 data are missing, wave 4 data are used. The highest grade completed variable comes from wave 4 responses where students report the highest education level achieved. The responses are categorical for 8th grade or less, some high school, high school graduate, etc. These categorical variables are converted to years of schooling for easier interpretation of the coefficients. To test whether there are lasting relationships beyond schooling, wave 4 variables for household income and whether the respondent used welfare since the last survey are also used.

Other dependent variables include whether a student participates in a sport, whether a student participates in a club, and various measures of one's school experience. The sport and club variables are coded as 1 if a student reports participating in a sport or a school club, respectively, on the in-school survey and 0 otherwise. The in-school survey has students report whether they feel "a part of this school" or "happy to be at this school". These variables are coded as 1 if students strongly agree or agree and 0 otherwise. The in-home survey asks students how much "teachers care about you". This variable is coded as a 1 if students report very much or quite a bit and 0 otherwise.

Controls for health and cognitive ability are included as Case and Paxson (2008) suggest that they may drive relationships between height and outcomes. Direct measures for health come from questions in waves 1 and 2 that ask respondents to report on their general health. Parental schooling is included as a control because it tends to be correlated with both health and children's cognitive ability. Other controls include race, gender, age, grade level, and school fixed effects. 
Table 2 provides descriptive statistics for each of the outcome variables described, height and school size variables, as well as the control variables. The table presents the data separated by big and small schools and also by individuals above and below the median height. Big schools are defined as schools above the median cohort size in the data while small schools are at or below the median cohort size. Median height is defined as the median height in the data by age and gender. A look at the average outcome variables in the raw data suggests that students above median height perform slightly better than those below the median in big schools. However, the performance gains are smaller or reversed for students above the median height in small schools. The next section further assesses the association of height with outcomes.

\section{Height and Outcomes}

Tables 3 and 4 show the correlations between height and outcomes. The first column for each outcome controls only for gender and race. Table 3, column 1 shows that an extra inch of height is associated with an increase in reported GPA by about 0.013 points. This means that a foot of difference in height is associated with an increase in GPA by approximately one-fifth of a standard deviation on average. The results are much smaller for transcript GPA and not statistically significant. Column 9 in Table 3 shows that an inch of height is correlated with an increase in the probability of graduation by $0.0045^{6}$ This means that someone who is a foot

\footnotetext{
${ }^{6}$ Note that a linear probability model is used for all binary outcomes. Probit models give similar results but interaction coefficients estimated with non-linear models are not easily interpretable and are difficult to present (see Ai and Norton (2003) and Norton, Wang, and Ai (2004)). One concern is that sometimes interaction effects change sign across predicted probabilities. Overall, this is not the case for the results in this paper.
} 
taller than their peer is almost 5 percentage points more likely to graduate from high school on average. Column 1 of Table 4 shows that an extra inch of height is correlated with 0.047 additional years of schooling. Thus a foot increase in height is associated with over half a year of additional schooling on average. These results confirm the positive associations between height and outcomes that are found in the earlier height literature..$^{7}$ Tables 3 and 4 also break down the results across gender. This decomposition suggests that the positive correlation of height with outcomes is driven by males.

To test whether the academic gains extend to the labor market, the last two outcomes of Table 4 look at welfare use and household income in wave 4 of the survey. There are no significant relationships between height and welfare or income in this data. However, most individuals are in their late 20's at the time and current incomes may not be a good reflection of lifetime earnings..$^{8}$

The results in the second column for each outcome in Tables 3 and 4 show that the relationship between academic outcomes and height diminishes when additional controls and school fixed effects are included. The decline in the relationship between height and outcomes is large and the relationships are no longer significant in many cases. Thus, on average, height is not correlated with academic improvement once controls are included. Much of the fall is due to the addition of parental education, which is positively and significantly related to height in this sample. Case and Paxson (2008) show that intelligence and early life experiences related to the family

\footnotetext{
${ }^{7}$ Some papers have found nonlinearities in the relationship between height and cognitive outcomes and wages (see Hübler (2009) and Heineck (2009)). In this data, there is some evidence of increasing returns to height for high school graduation and female reported GPA as well as decreasing returns for male wages, but there is little evidence of other nonlinear relationships when squared terms are added to the regressions. Since the the main interaction results do not change with squared terms, these terms are not included or reported here.

${ }^{8}$ See Haider and Solon (2006).
} 
environment contribute positively to height correlations; thus we would expect the fall that we see between the first and second columns. This fall in the height coefficient may lead one to conclude that intelligence, health, and family background can explain all of the correlation we see between height and academic outcomes. The fall, however, is not uniform across school size. While the average association of height on outcomes tends towards zero once controls are added, in most cases, the height premium remains for students in large schools.

The third and fourth columns for each outcome in Tables 3 and 4 look at the relationship between height interacted with school size and academic outcomes. This allows for the association of height to vary across small and large schools. These interactions are positive and significant for all academic outcomes. That is, height has a more positive association with grade and graduation outcomes in bigger schools than in smaller schools. This relationship remains significant even when controls are added. Once again, separating results by gender shows that these differential associations of height on outcomes across school size are driven by males. For females, height has largely insignificant associations with outcomes and does not significantly vary across school size. While longer term outcomes such as schooling completion and welfare show a similar pattern across school size, there is not a significant interaction coefficient for income.

Table 5 shows the magnitude of the height relationship implied by the regressions with full controls for individuals in schools at the 25th, 50th, 75th, and 90th percentile of school size. In a school at the 25th percentile in size, an added inch of height is correlated with little to no improvements in academic or labor market outcomes. The exception is in transcript GPA where height actually has a negative association with performance in small schools. However, in a school at the 90th percentile of size, an 
added inch of height is correlated with an increase in reported GPA of 0.015 points, an insignificant increase in transcript GPA, an increase in the probability of graduating by 0.006 , and an increase in years of schooling by 0.05 . Moreover, the relationships for reported grades, graduating, and years of schooling remain significant at the 75th percentile. The break down by gender highlights the fact that for most outcomes tall males perform better than their shorter peers in large schools. Overall, height is not an important predictor of outcomes for females.

Although average associations with height may be accounted for by background variables, significant associations between height and most academic outcomes remain for male students in large schools. Moreover, the significant associations with height occur in both the 75 th and 90th percentile of school size seen in this sample. This means that height has a strong relationship with outcomes for a large portion of the student population.

\section{Height and School Programs}

Different hypotheses can account for the relationship between height and school size. One implication of the Persico et al. (2004) results is that taller adolescents are more likely to participate in human capital building opportunities. If taller individuals are better able to take advantage of these opportunities, this would result in an association between height and school performance. Moreover, this theory could explain the above results if opportunities to participate in activities are not uniform across height and if large schools have more competition for participation.

One activity where height is an asset and opportunities are more limited as school 
size increases is participation in school sports. It has been established that height is an advantage in most sports. A look at the height of athletes across various sports shows that participants are on average taller than the population at large. There are only a few sports where a relative short stature is an advantage: these include gymnastics, diving, and figure skating (Norton and Olds, 1996) which are not typical high school sports. If height is an advantage in playing sports, it follows that when there is competition for a spot on a limited sized team, the taller athlete will be more likely to earn the spot. Moreover, athletic participation is more limited in a large school (Postlewaite and Silverman, 2005). The AddHealth data confirm that students who attend large schools are less likely to participate in sports. As seen in Table 1, while $63 \%$ of the AddHealth sample who attend a school at the bottom quartile of school size play school sports, only $43 \%$ of individuals in a school at the top quartile of size participate $9^{9}$ Thus, in a small school, where team sizes are large relative to the student body, more individuals can participate and height is less likely to affect participation. However, in a large school where team sizes are relatively small compared to the student body and many students are "cut" from the team, taller students may be more likely to earn the limited roster spots.

The pattern of sports participation that theory predicts shows up in the AddHealth data. As seen in Table 6, the relationship between height and school sports participation follows a pattern similar to the relationship between height and academic outcomes. The interaction between height and school size in column 3 of Table 6 is positive and significant for the population as a whole and for each gender separately. While this association is not significant in all cases once controls and school fixed effects are added, all the coefficients remain positive. The first column in Table

\footnotetext{
${ }^{9}$ The data is not detailed enough to differentiate between club and varsity sports or sports outside of school. The differences may be even larger if we only look at varsity school sports or starting positions.
} 
8 reports the different correlations between height and sports participation by the quantile of school size. For a school at the 25th percentile of size, an extra inch of height is associated with a 0.011 point increase in the probability of playing sports while for schools at the 90th percentile of size, an extra inch of height is associated with a 0.016 increase in the probability of sports participation for the whole population. This gap grows larger when looking at the coefficients for males and females separately.

Sports participation can in turn impact academic outcomes. There are several reasons why athletic participation might improve schooling performance. First, school sports can provide incentives to stay in school and meet a minimum GPA in order to stay eligible to play sports. Sports participation can also develop human capital by teaching leadership skills, hard work, following instructions, and cooperation. In addition, sports can affect student outcomes through peer effects, by bringing together students who otherwise would not interact. Furthermore, the literature suggests that sports participation leads to improved academic and labor market outcomes (Rehberg and Schafar (1968); Long and Caudill (1991); Barron, Ewing, and Waddell (2000); Videon (2002); Kuhn and Weinberger (2005); Postlewaite and Silverman (2005); Stevenson (2010); and Gorry (2016)).10 These results support the suggestion made in Perisco et al. (2004) that taller students have differential access to opportunities in school. In particular, tall students may have different opportunities to play sports, with sports participation being more limited in large schools. These opportunities, in turn, may lead to the differential schooling outcomes we see across height and school size.

Although height predicts participation in sports, it is not clear whether height pre-

\footnotetext{
${ }^{10}$ The data used in this paper also shows that sports participation is associated with improved academic and labor market outcomes.
} 
dicts participation in other clubs or if the relationship varies by school size. The performance argument for tall individuals participating in sports does not hold for other clubs. Thus theory does not suggest that height should be an advantage in these clubs, but if intelligence drives height relationships or if there is a preference towards having tall members, we may see that being tall is important for getting into other types of school clubs as well. The second section of Table 6 shows the same regressions run for sports participation but now the dependent variable is participation in other clubs outside of sports. These clubs include language or subject clubs, music clubs such as band or choir, debate team, and others. The results show that there is, in fact, no relation between height and participation in other clubs. The 3rd and 4th column for these outcomes also show no differential relationship between height and club participation across school size. Thus, differential access to clubs outside of sports cannot explain the fact that tall students outperform their peers in large schools.

\section{Height and School Satisfaction}

Beyond sports participation, a second mechanism that may drive the differential relationship between height and outcomes across school size is attention from one's teachers and peers. As shown in Table 1, bigger schools have a larger student to teacher ratio and students are less likely to report their best friends as coming from their own school. These facts suggest that it may be more difficult to attract teachers' attention or make friends in a large school. If height helps attract attention from

teachers and peers, then it may be more important in large schools. Moreover, if this treatment lends itself to more instruction or higher self esteem, it may result in 
better schooling performance. This paper looks at three different measures of school satisfaction to test whether tall students are more satisfied with their schooling experience and assesses whether this can account for the differential height relationships across school size. The measures are whether students claim to feel a part of their school, happy at school, or feel that their teachers care.

Table 7 shows the relation between height and these school perceptions. These measures are not on average significantly related to height. However, the results relevant to this paper show up in the last two columns for each outcome. Here the data show that the association between height and perception measures is stronger in large schools than small schools as the interactions with height and school size are positive and significant. Table 8 shows that height does not have a significant association with school perception measures for students in schools at the 25th or 50th percentile of size, but height has a positive and significant association on these measures for students in schools at the 75 th and 90th percentile of size. Similar patterns are demonstrated when broken out by gender. The association with feeling a part of school or happy at school is stronger for females at large schools and the relationship between height and teachers caring is stronger for males at large schools. Since the association between height and outcomes is stronger for males, if these are the causal mechanisms that explain the height relationships, then it must be that these measures are more important for predicting successful male outcomes or that having teachers that care matters most for schooling outcomes. Overall, the results support the argument that taller students may command more human capital building resources in schools, particularly in large schools where there is more competition for these resources. 


\section{Conclusion}

A large literature is devoted to explaining differences in academic and labor market outcomes and identifying the channels which propagate such disparities. There is strong evidence that height is related to better academic, labor market, and health outcomes. Yet the channels through which tall individuals excel are not fully understood.

While there is convincing literature to suggest that height is a reflection of cognitive differences, this paper provides new evidence that differential treatment across stature may also contribute to the disparity in academic outcomes. In particular, large school settings are relatively more advantageous for tall male students. This is reflected through a height premium in several academic outcomes that only exists in

large schools. Furthermore, the evidence suggests that the disadvantage may develop because the tall students are better able to acquire human capital building resources in large school settings.

Schools are supposed to provide equality of opportunity to America's youth and not further enhance disparities across disadvantaged individuals. Understanding how large schools enhance inequality across stature can guide school policy to level the playing field across tall and short individuals. As schools continue to grow, it is important to provide equal access to educational opportunities to all individuals or the short students may be the ones that suffer. 


\section{References}

Ai, Chunrong and Edward Norton, "Interaction terms in logit and probit models," Economics Letters, 2003, 80, 123-129.

Barron, John M., Bradley T. Ewing, and Glen R. Waddell, "The Effects Of High School Athletic Participation On Education And Labor Market Outcomes," The Review of Economics and Statistics, August 2000, 82 (3), 409-421.

Becker, Gary, "The Theory of the Allocation of Time," Economics, May 2002, 45 (4), 415-444.

Berger, Abi, "Insulin-Like Growth Factor and Cognitive Function," British Medical Journal, January 2001, 322, 203.

Black, Sandra, Paul Devereux, and Kjell Salvones, "From the Cradle to the Labor Market? The Effect of Birth Weight on Adult Outcomes.," Quarterly Journal of Economics, February 2007, 122, 409-39.

Brener, Nancy D., Tim Mcmanus, Deborah A. Galuska, Richard Lowry, and Howell Wechsler, "Reliability and validity of self-reported height and weight among high school students," Journal of Adolescent Health, 2003, 32 (4), 281-287.

Case, Anne and Christina Paxson, "Height, Health, and Cognitive Function at Older Ages," American Economic Review: Papers and Proceedings, 2008, 98, $463-467$.

_ and _ , "Stature and Status: Height, Ability, and Labor Market Outcomes," The Journal of Political Economy, 2008, 116 (3), 499-532.

_ and _ , "Causes and Consequences of Early-Life Health," Demography, 2010, 47 - Supplement, S65-S85. 
_ , _, and Mahnaz Islam, "Making Sense of the Labor Market Height Premium: Evidence from the British Household Panel Survey," Economic Letters, 2009, 102, $174-176$.

Cohen, Arianne, The Tall Book: A Celebration of Life from on High, Bloomsbury, 2009.

Coleman, James S., "Athletics in High School," Annals of the American Academy of Political and Social Science, November 1961, 338, 33-43.

Downie, A. Bruce, Jean Mulligan, Robert Stratford, Peter Betts, and Linda Voss, "Are Short Normal Children at a Disadvantage? The Wessex Growth Study," British Medical Journal, January 1997, 314, 97-100.

Dunn, L.M. and L.M. Dunn, The Peabody Picture Vocabulary Test, Third Edition, American Guidance Services, 1997.

Gorry, Devon, "Heterogenous Effects of Sports Participation on Education and Labor Market Outcomes," Education Economics, 2016.

Haider, Steven and Gary Solon, "Life-Cycle Variation in the Association between Current and Lifetime Earnings," The American Economic Review, 2006, 96 (4), 1308-1320.

Harris, Kathleen Mullan, "The National Longitudinal Study of Adolescent Health (AddHealth), Waves I\&II, 1994-1996; Wave III, 2001-2002 [machine-readable data file and documentation]," 2008. Chapel Hill, NC: Carolina Population Center, University of North Carolina at Chapel Hill.

-, Florwy Francesca, Joyce Tabor, Pater S. Bearman, Jo Jones, and J Richard Udry, "The National Longitudinal Study 
of Adolescent Health: Research Design [WWW document]. URL: http://www.cpc.unc.edu/projects/addhealth/design," 2003.

Heineck, Guido, "Too tall to be smart? The relationship between height and cognitive abilities," Economics Letters, 2009, 105 (1), 78-80.

Hübler, Olaf, "The nonlinear link between height and wages in Germany, 19852004," Economics and Human Biology, 2009, 7 (2), 191-199.

Kuhn, Peter and Catherine Weinberger, "Leadership Skills and Wages," Journal of Labor Economics, 2005, 23 (3), 395-436.

Loh, Eng Seng, "The Economic Effects of Physical Appearance," Social Science Quarterly, October 1993, 74 (2).

Long, James E. and Steven B Caudill, "The Impact of Participation in Intercollegiate Athletics on Income and Graduation," The Review of Economics and Statistics, August 1991, 73 (3), 525-31.

Maloney, Michael T. and Robert E. McCormick, "An Examination of the Role That Intercollegiate Athletic Participation Plays in Academic Achievement: Athletes' Feats in the Classroom," The Journal of Human Resources, 1993, 28 (3), 555-570.

McCormick, Robert E. and Maurice Tinsley, "Athletics versus Academics? Evidence from SAT Scores," The Journal of Political Economy, October 1987, 95 (5), 1103-1116.

Norton, Edward, Hua Wang, and Chunrong Ai, "Computing interaction effects and standard errors in logit and probit models," The Stata Journal, 2004, 4 (2), 154-167. 
Norton, Kevin and Tim Olds, Anthropometrics: A Textbook of Body Measurement for Sports and Health Outcomes, New South Wales University Press, 1996.

Persico, Nicola, Andrew Postlewaite, and Dan Silverman, "The Effect of Adolescent Experience on Labor Market Outcomes: The Case of Height," The Journal of Political Economy, June 2004, 112 (5), 420-438.

Postlewaite, Andrew and Dan Silverman, "Social Isolation and Inequality," Journal of Economic Inequality, 2005, 3, 243-262.

Rehberg, Richard A. and Walter E. Schafer, "Participation in Interscholastic Athletics and College Expectations," The American Journal of Sociology, May 1968, 73 (6), 732-740.

Sargent, James and David Blanchflower, "Obesity and Stature in Adolescence and Earnings in Young Adulthood: Analysis of a British Cohort," Archives Pediatric and Adolescent Medicine, July 1994, 148, 681-87.

Silventoinen, Karri, "Determinants of Variation in Adult Body Height," J. Biosocial Sci., April 2003, 35, 463-85.

Steckel, Richard, "Stature and Standard of Living," Journal of Economic Literature, December 1995, 33 (4), 1903-40.

Stevenson, Betsey, "Beyond the Classroom: Using Title IX to Measure the Return to High School Sports," Review of Economics and Statistics, May 2010, 92 (2), 284-301.

U.S. Department of Education, National Center for Education Statistics, The Condition of Education 2005 (NCES 2005-094), Washington D.C.: U.S. Government Printing Office, 2005. 
Videon, Tami M., "Who Plays and Who Benefits: Gender, Interscholastic Athletics, and Academic Outcomes," Sociological Perspectives, May 2002, 45 (4), 415444. 
Table 1: Resources Across School Size

\begin{tabular}{l|cc}
\hline & Top Quartile of School Size & Bottom Quartile of School Size \\
\hline Student Teacher Ratio & 23.51 & $13.66^{* * *}$ \\
Sport Participation & 0.43 & $0.63^{* * *}$ \\
Club Participation & 0.36 & $0.52^{* * *}$ \\
Best Female Friend is From Own School & 0.76 & $0.83^{* * *}$ \\
Best Male Friend is From Own School & 0.74 & $0.81^{* * *}$ \\
\hline Significant differences across school size are indicated. & $* * * \mathrm{p}<0.01,{ }^{* *} \mathrm{p}<0.05, * \mathrm{p}<0.1$.
\end{tabular}


Table 2: Summary Statistics

\begin{tabular}{|c|c|c|c|c|}
\hline & \multicolumn{2}{|c|}{ Big Schools } & \multicolumn{2}{|c|}{ Small Schools } \\
\hline & Above Median Height & Median Height and Below & Above Median Height & Median Height and Below \\
\hline Height (in.) & $\begin{array}{l}69.72 \\
(3.42)\end{array}$ & $\begin{array}{l}65.37 \\
(3.12)\end{array}$ & $\begin{array}{l}69.70 \\
(3.25)\end{array}$ & $\begin{array}{l}65.23 \\
(3.09)\end{array}$ \\
\hline Cohort Size & $\begin{array}{l}1,738 \\
(431)\end{array}$ & $\begin{array}{l}1,796 \\
(468)\end{array}$ & $\begin{array}{c}644 \\
(277)\end{array}$ & $\begin{array}{c}629 \\
(284)\end{array}$ \\
\hline GPA1 & $\begin{array}{l}2.87 \\
(0.74)\end{array}$ & $\begin{array}{l}2.77 \\
(0.77)\end{array}$ & $\begin{array}{c}2.82 \\
(0.74)\end{array}$ & $\begin{array}{l}2.77 \\
(0.74)\end{array}$ \\
\hline GPA2 & $\begin{array}{l}2.70 \\
(0.74)\end{array}$ & $\begin{array}{l}2.70 \\
(0.76)\end{array}$ & $\begin{array}{l}2.63 \\
(0.84)\end{array}$ & $\begin{array}{l}2.65 \\
(0.76)\end{array}$ \\
\hline HS Diploma & 0.92 & 0.86 & 0.88 & 0.87 \\
\hline Highest Grade & $\begin{array}{l}14.68 \\
(1.99)\end{array}$ & $\begin{array}{l}14.40 \\
(1.95)\end{array}$ & $\begin{array}{l}14.33 \\
(2.02)\end{array}$ & $\begin{array}{l}14.27 \\
(2.04)\end{array}$ \\
\hline Welfare & 0.14 & 0.21 & 0.25 & 0.24 \\
\hline HH Income & $\begin{array}{l}70,528 \\
(38,799)\end{array}$ & $\begin{array}{l}65,847 \\
(39,064)\end{array}$ & $\begin{array}{l}63,069 \\
(36,517)\end{array}$ & $\begin{array}{l}62,458 \\
(36,335)\end{array}$ \\
\hline Female & 0.50 & 0.49 & 0.52 & 0.53 \\
\hline Age (months) & $\begin{array}{l}177.9 \\
(10.79)\end{array}$ & $\begin{array}{l}179.2 \\
(11.57)\end{array}$ & $\begin{array}{l}178.9 \\
(11.46)\end{array}$ & $\begin{array}{l}179.2 \\
(11.90)\end{array}$ \\
\hline Grade & $\begin{array}{l}9.94 \\
(0.80)\end{array}$ & $\begin{array}{l}9.96 \\
(0.82)\end{array}$ & $\begin{array}{c}9.95 \\
(0.82)\end{array}$ & $\begin{array}{c}9.94 \\
(0.80)\end{array}$ \\
\hline Black & 0.13 & 0.14 & 0.15 & 0.18 \\
\hline Asian & 0.03 & 0.11 & 0.01 & 0.04 \\
\hline Native American & 0.02 & 0.03 & 0.02 & 0.03 \\
\hline Hispanic & 0.06 & 0.15 & 0.02 & 0.04 \\
\hline Parent High School & 0.23 & 0.27 & 0.27 & 0.32 \\
\hline Parent Some College & 0.23 & 0.21 & 0.23 & 0.21 \\
\hline Parent College & 0.30 & 0.26 & 0.24 & 0.19 \\
\hline Parent Beyond College & 0.16 & 0.13 & 0.12 & 0.10 \\
\hline General Health 1 & $\begin{array}{l}2.04 \\
(0.89)\end{array}$ & $\begin{array}{l}2.10 \\
(0.86)\end{array}$ & $\begin{array}{l}2.10 \\
(0.88)\end{array}$ & $\begin{array}{l}2.12 \\
(0.90)\end{array}$ \\
\hline General Health 2 & $\begin{array}{l}2.03 \\
(0.89)\end{array}$ & $\begin{array}{l}2.06 \\
(0.91)\end{array}$ & $\begin{array}{l}2.09 \\
(0.87)\end{array}$ & $\begin{array}{l}2.12 \\
(0.87)\end{array}$ \\
\hline School Sport & 0.52 & 0.47 & 0.63 & 0.59 \\
\hline Other Club & 0.41 & 0.44 & 0.50 & 0.48 \\
\hline Happy at School & 0.57 & 0.54 & 0.59 & 0.59 \\
\hline Part of School & 0.55 & 0.52 & 0.60 & 0.60 \\
\hline Teachers Care & 0.47 & 0.46 & 0.47 & 0.48 \\
\hline
\end{tabular}

Standard deviations in parentheses. Median height calculated by age and gender in sample. Big schools are defined as above the median cohort size while small schools are defined as at or below median cohort size. Add Health sample weights are used. 


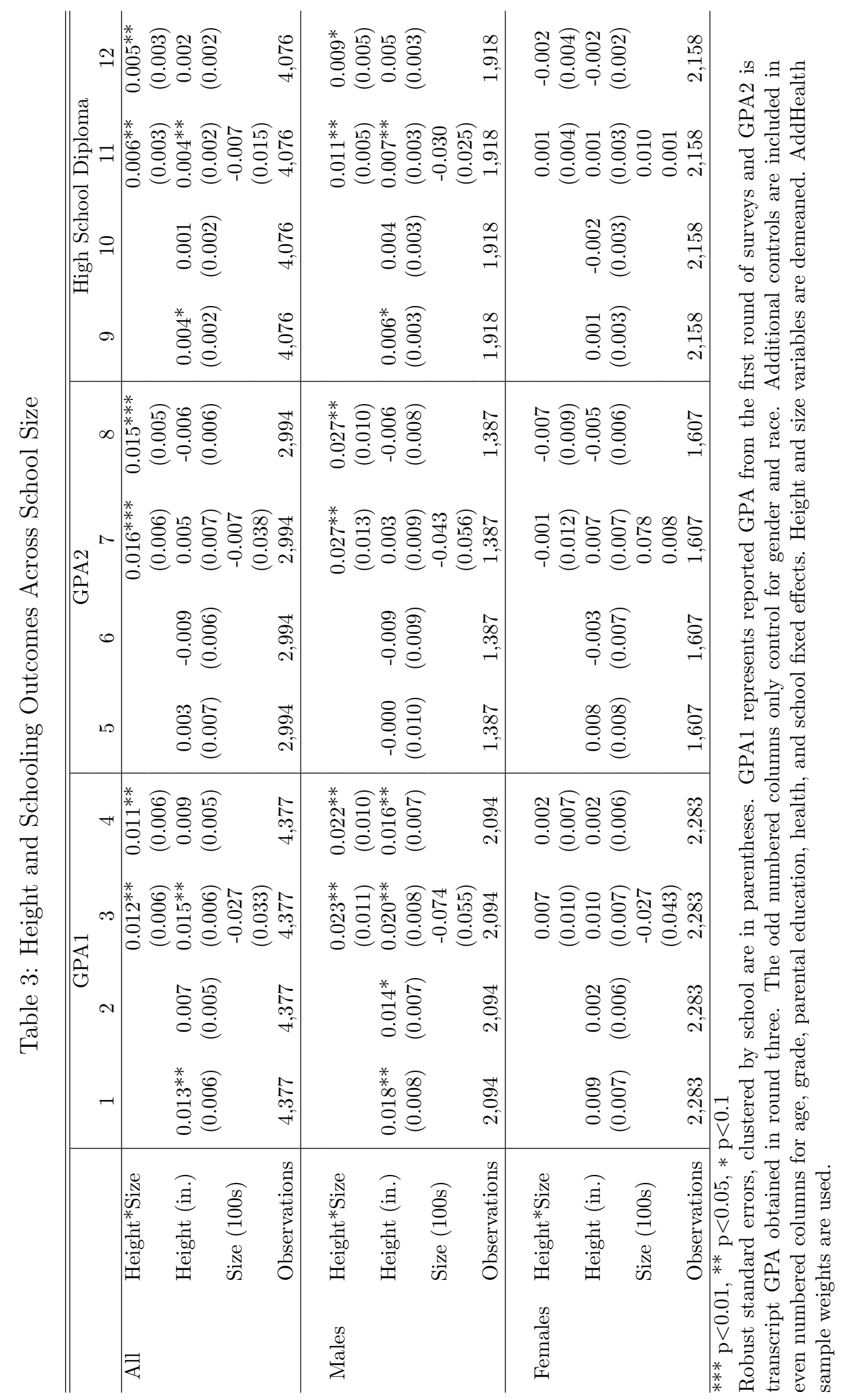




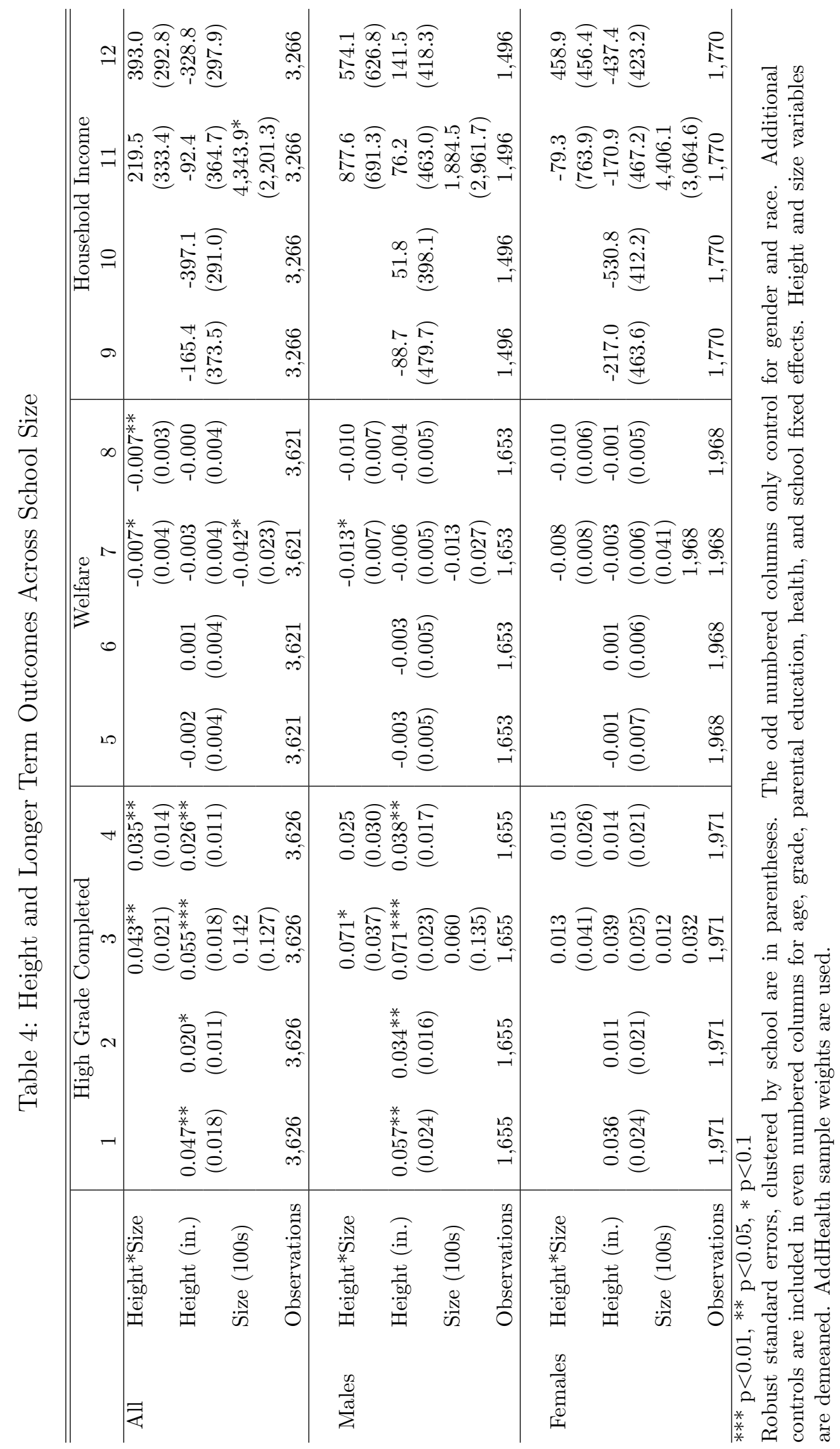


Table 5: Height Coefficients by School Size

\begin{tabular}{|c|c|c|c|c|c|c|c|}
\hline \multicolumn{2}{|c|}{ School Size Quantile } & GPA1 & GPA2 & HS Diploma & 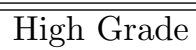 & $\overline{\text { Welfare }}$ & HH Income \\
\hline All & 25 th & $\begin{array}{c}0.002 \\
(0.005)\end{array}$ & $\begin{array}{c}-0.015^{* *} \\
(0.006)\end{array}$ & $\begin{array}{c}-0.001 \\
(0.002)\end{array}$ & $\begin{array}{c}0.006 \\
(0.012)\end{array}$ & $\begin{array}{c}0.003 \\
(0.004)\end{array}$ & $\begin{array}{c}-495.057 \\
(297.492)\end{array}$ \\
\hline & 50 th & $\begin{array}{c}0.007 \\
(0.005)\end{array}$ & $\begin{array}{l}-0.009 \\
(0.006)\end{array}$ & $\begin{array}{c}0.001 \\
(0.002)\end{array}$ & $\begin{array}{l}0.020^{*} \\
(0.011)\end{array}$ & $\begin{array}{c}0.001 \\
(0.004)\end{array}$ & $\begin{array}{l}-334.109 \\
(278.050)\end{array}$ \\
\hline & 75 th & $\begin{array}{c}0.018^{* *} \\
(0.008)\end{array}$ & $\begin{array}{c}0.006 \\
(0.007)\end{array}$ & $\begin{array}{l}0.006^{*} \\
(0.003)\end{array}$ & $\begin{array}{c}0.056^{* * *} \\
(0.018)\end{array}$ & $\begin{array}{l}-0.006 \\
(0.005)\end{array}$ & $\begin{array}{c}78.293 \\
(400.449)\end{array}$ \\
\hline & 90 th & $\begin{array}{c}0.019^{* *} \\
(0.009) \\
\end{array}$ & $\begin{array}{c}0.008 \\
(0.008) \\
\end{array}$ & $\begin{array}{l}0.007^{*} \\
(0.004) \\
\end{array}$ & $\begin{array}{c}0.058^{* * *} \\
(0.019)\end{array}$ & $\begin{array}{l}-0.007 \\
(0.005)\end{array}$ & $\begin{array}{c}108.189 \\
(415.485) \\
\end{array}$ \\
\hline Males & 25 th & $\begin{array}{c}0.004 \\
(0.007)\end{array}$ & $\begin{array}{c}-0.021^{* *} \\
(0.009)\end{array}$ & $\begin{array}{c}0.000 \\
(0.004)\end{array}$ & $\begin{array}{c}0.024 \\
(0.004)\end{array}$ & $\begin{array}{c}0.001 \\
(0.006)\end{array}$ & $\begin{array}{c}-99.309 \\
(478.377)\end{array}$ \\
\hline & 50 th & $\begin{array}{l}0.013^{*} \\
(0.007)\end{array}$ & $\begin{array}{l}-0.010 \\
(0.008)\end{array}$ & $\begin{array}{c}0.004 \\
(0.003)\end{array}$ & $\begin{array}{c}0.034^{* *} \\
(0.003)\end{array}$ & $\begin{array}{l}-0.003 \\
(0.005)\end{array}$ & $\begin{array}{c}127.002 \\
(411.919)\end{array}$ \\
\hline & 75 th & $\begin{array}{c}0.035^{* * *} \\
(0.013)\end{array}$ & $\begin{array}{c}0.017 \\
(0.014)\end{array}$ & $\begin{array}{c}0.013^{* *} \\
(0.006)\end{array}$ & $\begin{array}{l}0.059^{*} \\
(0.006)\end{array}$ & $\begin{array}{l}-0.013 \\
(0.009)\end{array}$ & $\begin{array}{c}706.888 \\
(759.347)\end{array}$ \\
\hline & 90 th & $\begin{array}{c}0.037^{* * *} \\
(0.014) \\
\end{array}$ & $\begin{array}{c}0.019 \\
(0.014) \\
\end{array}$ & $\begin{array}{c}0.014^{* *} \\
(0.006) \\
\end{array}$ & $\begin{array}{l}0.061^{*} \\
(0.006)\end{array}$ & $\begin{array}{l}-0.013 \\
(0.005)\end{array}$ & $\begin{array}{c}798.338 \\
(798.338)\end{array}$ \\
\hline Females & 25 th & $\begin{array}{c}0.001 \\
(0.007)\end{array}$ & $\begin{array}{l}-0.001 \\
(0.008)\end{array}$ & $\begin{array}{l}-0.002 \\
(0.003)\end{array}$ & $\begin{array}{c}0.005 \\
(0.024)\end{array}$ & $\begin{array}{c}0.005 \\
(0.007)\end{array}$ & $\begin{array}{l}-644.868 \\
(408.448)\end{array}$ \\
\hline & 50 th & $\begin{array}{c}0.002 \\
(0.006)\end{array}$ & $\begin{array}{l}-0.004 \\
(0.006)\end{array}$ & $\begin{array}{c}-0.002 \\
(0.002)\end{array}$ & $\begin{array}{c}0.011 \\
(0.021)\end{array}$ & $\begin{array}{c}0.001 \\
(0.005)\end{array}$ & $\begin{array}{l}-475.434 \\
(384.671)\end{array}$ \\
\hline & 75 th & $\begin{array}{c}0.003 \\
(0.008)\end{array}$ & $\begin{array}{l}-0.011 \\
(0.010)\end{array}$ & $\begin{array}{l}-0.004 \\
(0.005)\end{array}$ & $\begin{array}{c}0.026 \\
(0.033)\end{array}$ & $\begin{array}{l}-0.009 \\
(0.007)\end{array}$ & $\begin{array}{c}-41.285 \\
(615.904)\end{array}$ \\
\hline & 90 th & $\begin{array}{c}0.004 \\
(0.009)\end{array}$ & $\begin{array}{c}-0.011 \\
(0.010)\end{array}$ & $\begin{array}{l}-0.004 \\
(0.005)\end{array}$ & $\begin{array}{c}0.027 \\
(0.034)\end{array}$ & $\begin{array}{l}-0.010 \\
(0.007)\end{array}$ & $\begin{array}{c}-9.813 \\
(641.678)\end{array}$ \\
\hline
\end{tabular}

*** $\mathrm{p}<0.01, * * \mathrm{p}<0.05, * \mathrm{p}<0.1$

Robust standard errors, clustered by school are in parentheses. Each number represents the marginal correlation of height calculated from the 4th column of each outcome in Tables 3 and 4 at the given quantile of school size. The quantile sizes are computed using the sample data. 
Table 6: Participation and Height Across School Size

\begin{tabular}{|c|c|c|c|c|c|c|c|c|c|}
\hline & \multicolumn{4}{|c|}{ School Sport } & \multicolumn{4}{|c|}{ Other Club } \\
\hline & & 1 & 2 & 3 & 4 & 5 & 6 & 7 & 8 \\
\hline \multirow[t]{4}{*}{ All } & Height*Size & & & $\begin{array}{l}0.006^{*} \\
(0.003)\end{array}$ & $\begin{array}{c}0.004 \\
(0.004)\end{array}$ & & & $\begin{array}{c}0.000 \\
(0.006)\end{array}$ & $\begin{array}{c}0.001 \\
(0.006)\end{array}$ \\
\hline & Height (in.) & $\begin{array}{c}0.014^{* * * *} \\
(0.004)\end{array}$ & $\begin{array}{c}0.012^{* * *} \\
(0.003)\end{array}$ & $\begin{array}{c}0.015^{* * *} \\
(0.003)\end{array}$ & $\begin{array}{c}0.013^{* * *} * \\
(0.003)\end{array}$ & $\begin{array}{c}0.001 \\
(0.004)\end{array}$ & $\begin{array}{l}-0.002 \\
(0.003)\end{array}$ & $\begin{array}{c}0.001 \\
(0.004)\end{array}$ & $\begin{array}{l}-0.001 \\
(0.003)\end{array}$ \\
\hline & Size (100s) & & & $\begin{array}{c}-0.079 * * * \\
(0.026)\end{array}$ & & & & $\begin{array}{c}-0.058^{* * *} \\
(0.021)\end{array}$ & \\
\hline & Observations & 4,394 & 4,394 & 4,394 & 4,394 & 4,394 & 4,394 & 4,394 & 4,394 \\
\hline \multirow[t]{4}{*}{ Males } & Height*Size & & & $\begin{array}{l}0.011^{*} \\
(0.007)\end{array}$ & $\begin{array}{c}0.004 \\
(0.006)\end{array}$ & & & $\begin{array}{l}-0.008 \\
(0.006)\end{array}$ & $\begin{array}{c}-0.006 \\
(0.007)\end{array}$ \\
\hline & Height (in.) & $\begin{array}{c}0.010^{* *} \\
(0.005)\end{array}$ & $\begin{array}{c}0.013^{* * *} \\
(0.005)\end{array}$ & $\begin{array}{c}0.011^{* *} \\
(0.005)\end{array}$ & $\begin{array}{c}0.014^{* * *} \\
(0.005)\end{array}$ & $\begin{array}{l}-0.003 \\
(0.005)\end{array}$ & $\begin{array}{l}-0.006 \\
(0.004)\end{array}$ & $\begin{array}{l}-0.004 \\
(0.004)\end{array}$ & $\begin{array}{l}-0.006 \\
(0.004)\end{array}$ \\
\hline & Size (100s) & & & $\begin{array}{c}-0.108^{* * *} \\
(0.037)\end{array}$ & & & & $\begin{array}{l}-0.022 \\
(0.030)\end{array}$ & \\
\hline & Observations & 2,104 & 2,104 & 2,104 & 2,104 & 2,104 & 2,104 & 2,104 & 2,104 \\
\hline \multirow[t]{4}{*}{ Females } & Height*Size & & & $\begin{array}{c}0.012^{* *} \\
(0.006)\end{array}$ & $\begin{array}{c}0.010^{*} \\
(0.006)\end{array}$ & & & $\begin{array}{c}0.003 \\
(0.007)\end{array}$ & $\begin{array}{c}0.001 \\
(0.006)\end{array}$ \\
\hline & Height (in.) & $\begin{array}{c}0.020^{* * *} \\
(0.005)\end{array}$ & $\begin{array}{c}0.013^{* *} \\
(0.006)\end{array}$ & $\begin{array}{c}0.021^{* * *} \\
(0.005)\end{array}$ & $\begin{array}{c}0.015^{* * *} \\
(0.005)\end{array}$ & $\begin{array}{c}0.006 \\
(0.007)\end{array}$ & $\begin{array}{c}0.003 \\
(0.005)\end{array}$ & $\begin{array}{c}0.006 \\
(0.006)\end{array}$ & $\begin{array}{r}0.003 \\
(0.005)\end{array}$ \\
\hline & Size (100s) & & & $\begin{array}{c}-0.050^{*} \\
(0.028)\end{array}$ & & & & $\begin{array}{l}-0.058 \\
(0.038)\end{array}$ & \\
\hline & Observations & 2,290 & 2,290 & 2,290 & 2,290 & 2,290 & 2,290 & 2,290 & 2,290 \\
\hline
\end{tabular}

*** $\mathrm{p}<0.01,{ }^{* *} \mathrm{p}<0.05, * \mathrm{p}<0.1$

Robust standard errors, clustered by school are in parentheses. The odd numbered columns only control for gender and race. Additional controls are included in even numbered columns for age, grade, parental education, health, and school fixed effects. Height and size variables are demeaned. AddHealth sample weights are used. 


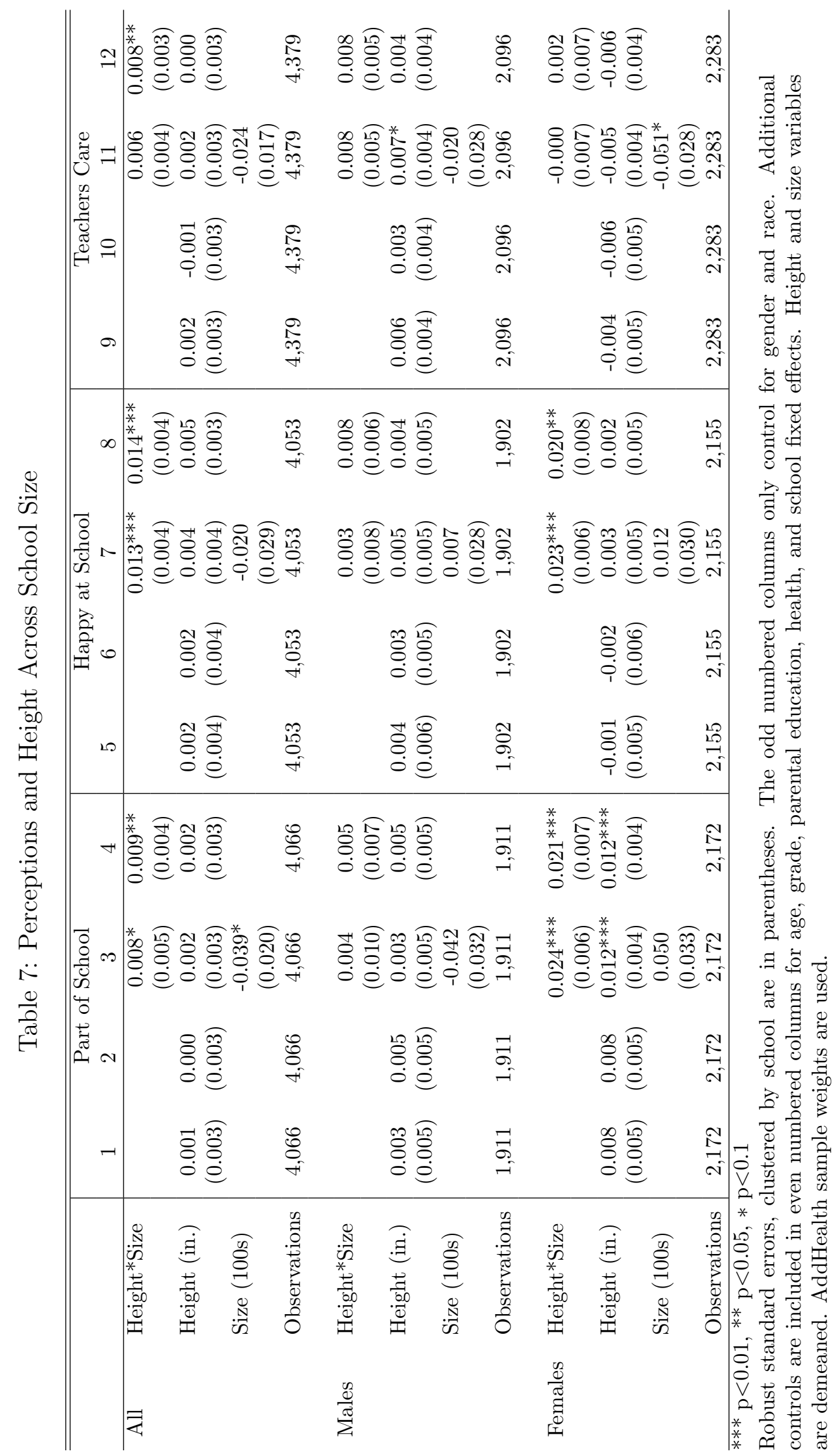


Table 8: Coefficients of Height on Participation and Perceptions by School Size

\begin{tabular}{|c|c|c|c|c|c|c|}
\hline \multicolumn{2}{|c|}{ School Size Quantile } & School Sport & Other Club & Part of School & Happy at School & Teachers Care \\
\hline All & 25 th & $\begin{array}{c}0.011^{* * *} \\
(0.004)\end{array}$ & $\begin{array}{c}-0.002 \\
(0.004)\end{array}$ & $\begin{array}{l}-0.003 \\
(0.004)\end{array}$ & $\begin{array}{l}-0.003 \\
(0.004)\end{array}$ & $\begin{array}{c}-0.004 \\
(0.004)\end{array}$ \\
\hline & 50 th & $\begin{array}{c}0.012^{* * *} \\
(0.003)\end{array}$ & $\begin{array}{l}-0.002 \\
(0.003)\end{array}$ & $\begin{array}{c}0.001 \\
(0.003)\end{array}$ & $\begin{array}{c}0.002 \\
(0.003)\end{array}$ & $\begin{array}{l}-0.001 \\
(0.003)\end{array}$ \\
\hline & 75 th & $\begin{array}{c}0.016^{* * *} \\
(0.004)\end{array}$ & $\begin{array}{c}0.000 \\
(0.007)\end{array}$ & $\begin{array}{l}0.009^{*} \\
(0.005)\end{array}$ & $\begin{array}{c}0.017^{* * *} \\
(0.005)\end{array}$ & $\begin{array}{l}0.007^{*} \\
(0.004)\end{array}$ \\
\hline & 90 th & $\begin{array}{c}0.016^{* * *} \\
(0.005)\end{array}$ & $\begin{array}{c}0.000 \\
(0.007)\end{array}$ & $\begin{array}{l}0.010^{*} \\
(0.005)\end{array}$ & $\begin{array}{c}0.018^{* * *} \\
(0.005)\end{array}$ & $\begin{array}{l}0.007^{*} \\
(0.004)\end{array}$ \\
\hline Males & 25 th & $\begin{array}{c}0.011^{* *} \\
(0.005)\end{array}$ & $\begin{array}{l}-0.003 \\
(0.006)\end{array}$ & $\begin{array}{c}0.003 \\
(0.006)\end{array}$ & $\begin{array}{c}0.000 \\
(0.007)\end{array}$ & $\begin{array}{c}0.000 \\
(0.004)\end{array}$ \\
\hline & 50 th & $\begin{array}{c}0.013^{* * *} \\
(0.005)\end{array}$ & $\begin{array}{l}-0.006 \\
(0.004)\end{array}$ & $\begin{array}{c}0.005 \\
(0.005)\end{array}$ & $\begin{array}{c}0.003 \\
(0.005)\end{array}$ & $\begin{array}{c}0.003 \\
(0.004)\end{array}$ \\
\hline & 75 th & $\begin{array}{c}0.017^{* *} \\
(0.007)\end{array}$ & $\begin{array}{l}-0.011 \\
(0.007)\end{array}$ & $\begin{array}{c}0.010 \\
(0.008)\end{array}$ & $\begin{array}{l}0.011^{*} \\
(0.006)\end{array}$ & $\begin{array}{l}0.011^{*} \\
(0.007)\end{array}$ \\
\hline & 90 th & $\begin{array}{c}0.018^{* *} \\
(0.008)\end{array}$ & $\begin{array}{l}-0.012 \\
(0.007)\end{array}$ & $\begin{array}{c}0.010 \\
(0.008)\end{array}$ & $\begin{array}{l}0.012^{*} \\
(0.006)\end{array}$ & $\begin{array}{l}0.012^{*} \\
(0.007)\end{array}$ \\
\hline Females & 25 th & $\begin{array}{c}0.010 \\
(0.006)\end{array}$ & $\begin{array}{c}0.002 \\
(0.006)\end{array}$ & $\begin{array}{l}-0.009 \\
(0.007)\end{array}$ & $\begin{array}{l}-0.008^{*} \\
(0.005)\end{array}$ & $\begin{array}{l}-0.007 \\
(0.006)\end{array}$ \\
\hline & 50 th & $\begin{array}{c}0.014^{* *} \\
(0.005)\end{array}$ & $\begin{array}{c}0.003 \\
(0.005)\end{array}$ & $\begin{array}{l}-0.001 \\
(0.006)\end{array}$ & $\begin{array}{c}0.002 \\
(0.004)\end{array}$ & $\begin{array}{l}-0.006 \\
(0.005)\end{array}$ \\
\hline & 75 th & $\begin{array}{c}0.024^{* * *} \\
(0.007)\end{array}$ & $\begin{array}{c}0.004 \\
(0.008)\end{array}$ & $\begin{array}{c}0.018^{* *} \\
(0.009)\end{array}$ & $\begin{array}{c}0.027^{* * *} \\
(0.008)\end{array}$ & $\begin{array}{l}-0.004 \\
(0.007)\end{array}$ \\
\hline & 90 th & $\begin{array}{c}0.024^{* * *} \\
(0.007)\end{array}$ & $\begin{array}{c}0.004 \\
(0.008)\end{array}$ & $\begin{array}{c}0.020^{* *} \\
(0.009)\end{array}$ & $\begin{array}{c}0.029^{* * *} \\
(0.009)\end{array}$ & $\begin{array}{l}-0.004 \\
(0.008)\end{array}$ \\
\hline
\end{tabular}

*** $\mathrm{p}<0.01, * * \mathrm{p}<0.05, * \mathrm{p}<0.1$

Robust standard errors, clustered by school are in parentheses. Each number represents the marginal correlation of height calculated from the 4th column of each outcome in Tables 6 and 7 at the given quantile of school size. The quantile sizes are computed using the sample data. 